\title{
The Natural Product NI-07, Is Effective Against Breast Cancer Cells While Showing No Cytotoxicity to Normal Cells
}

\author{
Lauren S. Gollahon ${ }^{*}, 1$, , Yunseong Jeong ${ }^{\S, 2}$, Velvetlee Finckbone ${ }^{1}$, Kyungwoo Lee ${ }^{1}$ and Jong-Sang Park ${ }^{2}$ \\ ${ }^{1}$ Department of Biological Sciences, Texas Tech University, Lubbock, Texas, 79409, USA \\ ${ }^{2}$ School of Chemistry \& Molecular Engineering, Seoul National University, Seoul 151-742, Republic of Korea
}

\begin{abstract}
With the exception of a few anticancer agents, most breast cancer chemotherapeutics currently used have devastating effects on normal cells. We investigated the effectiveness of the natural product NI-07, derived from Arctium lappa, to determine its killing potential on breast cancer cells and its cytotoxic effects in breast normal cells. The breast cancer cell lines HCC1419, MCF7, MDA-MB-231, MDA-MB-468, SKBR3, the normal mammary epithelial cell line HME $50 \mathrm{HT}$ and the normal mammary fibroblast cell line CCD-1074sk were analyzed in concurrently treated cultures of NI-07, Taxol ${ }^{\mathrm{TM}}$ or Untreated. NI-07- treated and $\mathrm{Taxol}^{\mathrm{TM}}$-treated cells were cultured for two weeks to assess cell resistance/recovery. Cell viability was determined by cell counts, Trypan Blue exclusion and microscopy. Additionally, cell viability and cytotoxicity were measured by XTT. Statistical significance $(\mathrm{p} \leq 0.05)$ of NI-07 to Untreated or Taxol ${ }^{\mathrm{TM}}$ was first determined using Two-Way ANOVA. Identified significant differences were further analyzed by One-Way ANOVA and Tukey's test for honestly significant differences. The effect size of NI-07 compared to untreated or Taxol ${ }^{\mathrm{TM}}$ was determined using Cohen's $d$. Our results showed significant declines in cell viability occurring in NI-07- treated cancer cells after 48 hours of treatment in contrast to the more rapid effect of Taxol ${ }^{\mathrm{TM}}(<24 \mathrm{~h})$. Additionally, cancer cell recovery was less effective in NI-07 versus Taxol ${ }^{\mathrm{TM}}$. Furthermore, NI-07 showed no cytotoxicity in normal cells. This lack of cytotoxicity, coupled with its killing efficiency in cancer cells, suggests that NI-07 could potentially make a strong anti-cancer compound or neo-adjuvant to current chemotherapy-based treatments.
\end{abstract}

Keywords: Breast cancer, NI-07, Natural product, Cytotoxicity, Normal cells.

\section{INTRODUCTION}

To date, breast cancer is the most prevalent female cancer with $10 \%$ of all new cancers diagnosed. Not only is breast cancer the most common cancer in women in both developing and developed areas, it is also globally, their principle cause of death from cancer [1]. Within the U.S., breast cancer is the leading female cancer and mortality rates are second only to lung cancer $[1,2]$. Statistically, a new breast cancer case is diagnosed every three minutes, and a death attributed to breast cancer occurs every 13 minutes [3].

Current breast cancer therapies are varied in their targets and effectively kill most of the cancer cells [2, 4-9]. Many of these drugs are delivered as cocktails $[5,10]$. While newer, water-soluble compounds are being developed for their potential anti-breast cancer efficacy [11-15], delivery and specificity remain major obstacles [16]. In all cases, side effects can be devastating and during treatment, the patient's quality of life is poor. Many patients are given immunosuppressive drugs and anti-nausea medication [1719]. These side effects are a result of the chemotherapeutics on the normal cells and tissues. Trastuzumab, the newest anticancer treatment, targets cancer cells that express a,

\footnotetext{
*Address correspondence to this author at the Department of Biological Sciences, Texas Tech University, Box 43131, Lubbock, TX 79409, USA; Tel: (806) 742-4464, Ext. 234; Fax: (806) 742-2963; E-mail: Lauren.gollahon@ttu.edu

${ }^{\S}$ These authors made equal contributions.
}

particular receptor (human epidermal growth factor receptor 2 or HER2) [20, 21]. Although the side effects are less [22] comparatively speaking, this treatment is only effective in $20 \%$ of breast cancer cases. That means of the 207,000 reported cases for 2010 in the U.S., Trastuzumab does not work for over 165,000 patients. Therefore, it is imperative that this growing global health problem be addressed with new anticancer drugs, giving clinicians more options for designing treatment strategies, with more impact on cancer cells while reducing cytotoxicity to normal cells.

Natural products are defined as chemical compounds or substances, produced by a living organism that possesses biological or pharmacological activities. These activities are generally used as selection criteria in drug discovery, with the ultimate goal of drug design. While bioprospecting for natural products as cancer treatments has yielded compounds such as the taxanes that have improved treatments and increased survivorship, one of the biggest hurdles yet to be overcome is the cytotoxic effects to normal cells [23].

In this study, we tested a new potential anticancer compound NI-07, derived from Arctium lappa, that represents a paradigm shift in current anticancer treatments. A. lappa, commonly known as Greater Burdock or Edible Burdock has a vast distribution [24]. This tall member of the Astreraceae family has a fleshy, edible taproot that has been used as a medicinal herb in Asian cultures for many years [25]. Recently, its anticancer properties have come under closer scrutiny [26-29]. Further investigation by our group resulted in the identification of a novel bioreactive species. 
We hypothesized that this novel water-soluble, natural product NI-07, extracted from A. lappa, would effectively treat breast cancer cells while reducing cytotoxicity to normal cells. Herein, we describe the structural determination of the active species isolated from A. lappa, using ${ }^{1} \mathrm{H}-\mathrm{NMR}$. Cell death induced by NI-07 showed distinct morphological differences compared to the widely used and well-known anti-cancer agent Taxol ${ }^{\mathrm{TM}}$.

In this study, we demonstrate that NI-07 was effective at killing breast cancer cells while exhibiting no cytotoxic effects to normal cells. Based on the following results we feel that NI-07 shows great potential as a possible anticancer treatment against breast cancer, while potentially reducing side effects to the patient during treatment.

\section{MATERIALS AND METHODS:}

\section{Purification Of NI-07}

NI-07 extract was supplied by Yusahng LLC as a dark green powder. This compound was dissolved in distilled water at a concentration of $0.6 \mathrm{mg} / \mathrm{mL}$. The solution was then filtered through $0.2 \mu \mathrm{m}$ pore size syringe filters (PTFE, $25 \mathrm{~mm}$; Whatman ${ }^{\circledR}$, USA) at $120^{\circ} \mathrm{C}, 80^{\circ} \mathrm{C}, 60^{\circ} \mathrm{C}, 30^{\circ} \mathrm{C}$ and $12^{\circ} \mathrm{C}$ in sequence, after incubating the solution at each temperature for at least $30 \mathrm{~min}$. The final filtered solution was freeze-dried under vacuum to yield a bright brownyellow powder.

\section{Proton Nuclear Magnetic Resonance $\left({ }^{1}\right.$ H-NMR) Spectro- scopy and Mass Spectroscopy Measurements}

Twelve milligrams of the final purified sample (hydrophilic powder) were dissolved in $0.7 \mathrm{~mL}$ of deuterium oxide $\left(\mathrm{D}_{2} \mathrm{O}\right)$ in an NMR tube (Model No. XR-509-UP-7; Norell ${ }^{\mathrm{TM}}$, USA) and measured using ${ }^{1} \mathrm{H}-\mathrm{NMR}$ (1D) (Bruker Avance $600,600 \mathrm{MHz}, 14.1$ Tesla) to confirm a product's structure. The measurement was conducted in the hightemperature mode (specifically $35^{\circ} \mathrm{C}$ ) for 32 scan numbers. To determine the molecular weight of the target chemicals, electrospray ionization mass spectrometry (ESI-MS) analysis was performed using a Thermo Finnigan USA ESI-MS, (Model No. LCQ API-3000). For this experiment, $0.5 \mathrm{~mL}$ of the aqueous solution of the final purified sample (concentration, $1.1 \mathrm{mg} / \mathrm{mL}$ ) was prepared. The target molecules were ionized (negatively charged) during the ion spray step in the mass spectrometer.

\section{Analysis of Viscosity, Solubility, Density, and Boiling/ Melting Point of the Sample Solution}

A solution consisting of the purified powder in water $(0.012 \mathrm{mg} / \mathrm{mL})$ was prepared and tested for its viscosity, and density. The mass value $(\mathrm{g})$ of $1 \mathrm{~mL}$ of this solution at $25^{\circ} \mathrm{C}$ is equal to density value. Viscosity values of the sample solution (volume $=20 \mathrm{~mL}$ ) were confirmed on a viscometer (Model No. HADV-1+; Brookfield, USA) at $10^{\circ} \mathrm{C}, 20^{\circ} \mathrm{C}$, $25^{\circ} \mathrm{C}, 30^{\circ} \mathrm{C}$ and $40^{\circ} \mathrm{C}$. Analysis to determine the boiling and melting points (b.p./m.p.) were carried out under $1 \mathrm{~atm}$ (normal atmospheric pressure) in a completely sealed globe box. Three milliliters of saturated NI-07 in water $\left(25^{\circ} \mathrm{C}\right)$ was prepared for solubility testing. After centrifugation $(3000 \mathrm{~g}, 3$ min) of the solution, $1 \mathrm{~mL}$ of supernatant was freeze-dried to obtain NI-07 in powder form. The mass values (g) of A (powder) and $\mathrm{B}(1 \mathrm{ml}$ of supernatant) are necessary to estimate solubility through the equation: Solubility $($ grams $/ 100 \mathrm{~g}$ of water $)=100 * \mathrm{~A} /(\mathrm{B}-\mathrm{A})$.

\section{Cell Lines and Culture Conditions}

All cell lines, except HME 50 HT were purchased from American Type Cell Collection (ATCC) within the last 6 months. The HME 50 HT cell line was a kind gift of Brittany Shea-Herbert, (Indiana University). All cell lines were cultured under humid $37^{\circ} \mathrm{C}$ in $5 \% \mathrm{CO}_{2}$ conditions. Tumor cells tested were as follows: HCC1419 ([30], ATCC\#CRL2326); MCF7 ([31], ATCC\#HTB-22); MDA-MB-231 ([32], ATCC\#HTB-26), MDA-MD-468 ([33], ATCC\#HTB-132), SKBR3 ([34], ATCC\#HTB-30). Diploid human mammary epithelial (HME 50) cells were isolated from a Li-Fraumeni Syndrome patient [35] and immortalized with hTERT [36]. CCD-1074sk normal human mammary fibroblasts were purchased from ATCC (ATCC\#CRL-2090).

\section{Cell Treatments}

NI-07 formulations of $1 \mathrm{X}$ were supplied by Yusahng LLC, dried by speed vacuum (Thermo, USA) and resuspended with sterile water to $100 \mathrm{X}$. The molecular weight of NI-07 dihydrate is $191.19 \mathrm{~g} / \mathrm{mole}$. The liquid concentrate was added to the media formulations at the time of treatment to a final concentration of $20 \mathrm{X}$. The $20 \mathrm{X}$ dosage equals a concentration of $36.6 \mathrm{mM}$. Titration experiments (data not shown) determined this to be the approximate lowest lethal concentration to kill $\sim 50 \%$ of the cells (LC50) over the treatment period. NI-07 test cells were continuously exposed for 7 days. Medium alone (Taxol ${ }^{\mathrm{TM}}$ and untreated) or Medium with NI-07 was refreshed on day 3. At $7 \mathrm{~d}$, treatment medium was replaced with fresh, untreated medium for the second week. Concurrently, Taxol ${ }^{\mathrm{TM}}$ at concentrations of 2.2e-7 M were added for $24 \mathrm{~h}$ to parallel cultures of cells as previously described [37] as a positive control for cytotoxicity and cell damage. We [37] and others [38-40] have previously shown that the actions of Taxol ${ }^{\mathrm{TM}}$ on the cells is dependent on the dose administered. In this study, a specific clinically relevant Taxol ${ }^{\mathrm{TM}}$ dose, $2.5 \mu \mathrm{M}$ was used. This is the estimated plasma level concentration in patients administered a common dosage $135 \mathrm{mg} / \mathrm{m}^{2}$ for $3 \mathrm{~h}$ and $24 \mathrm{~h}$ infusion schedules, respectively [41]. Although the in vivo conditions are much more complicated, we tried to more closely simulate a clinically relevant phenomenon when comparing Taxol $^{\mathrm{TM}}$ treatment to NI-07 treatment. Medium alone was used as the negative control. Cells were collected in tandem. Time points analyzed were $0 \mathrm{~h}, 24 \mathrm{~h}, 48$ h, $4 \mathrm{~d}$, and $7 \mathrm{~d}$ for both weeks. Week 1 was designated LC50 and week 2, Recovery. Results were obtained from three separate experiments consisting of three biological replicates per experiment unless indicated otherwise.

\section{Cell Counts}

Cells were plated into 48-well CellBind ${ }^{\mathrm{TM}}$ plates (Corning, USA) at densities of 20,000 cells for normal cells and 10,000 - 20,000 cells for tumor cells. Plating density was optimized based on cell cycle turn over rates. Twentyfour to $48 \mathrm{~h}$ after plating, cells were treated with NI-07 or Taxol $^{\mathrm{TM}}$. Cells were harvested using Trypsin-EDTA (Invitrogen, USA) at the designated time points. Total cells for each well were counted using a ViCell (Beckman Coulter, USA), which also determines cell viability by 
Trypan Blue exclusion. Therefore, both cell numbers and percentage of viable cells within the wells was obtained. LC50 curves were generated in the first week. Recovery curves were generated by culturing Taxol $^{\mathrm{TM}}$ or NI-07treated cells for a second week. At $7 \mathrm{~d}$, LC50 equals $0 \mathrm{~h}$ Recovery. Thus at $0 \mathrm{~h}$ Recovery, medium was exchanged with untreated medium for the remainder of the experiment and refreshed again at $3 \mathrm{~d}$ Recovery. Cells were collected at $0 \mathrm{~h}, 24 \mathrm{~h}, 48 \mathrm{~h}, 4 \mathrm{~d}$ and $7 \mathrm{~d}$. Analysis of untreated controls was not done in Recovery due to over confluence by the end of week 1 .

\section{XTT Cell Viability Assays}

The XTT assay is a widely accepted analysis technique for viability/cytotoxicity of anti-cancer drugs or other pharmaceutical compounds. The nonradioactive Roche Cell Proliferation Kit II (XTT) spectrophotometrically quantifies cell proliferation and viability based on tetrazolium salt XTT cleavage in the presence of an electron-coupling reagent. Only viable cells can produce the soluble formazan salt, based on glycolytic NAD $(\mathrm{P}) \mathrm{H}$ production. Therefore, the amount of formazan dye formed directly correlated to the number of metabolically active cells in the culture. Cytotoxicity is inversely proportional to viability.

Cells were seeded in a 96-well tissue culture plate at a density of 5,000 cells for tumor cells and 10,000 cells for normal cells. At each time point, cells were incubated with the XTT labeling mixture for approximately 10-12 hours. After this incubation period, the formazan dye formed was quantitated using a Spectramax Plus ELISA reader, (Molecular Devices). The optimal wavelength used in our experiments was $500 \lambda$. Values were generated using the software package, SoftMax Pro 4.8. Following manufacturer's instructions, cell viability was calculated separately for NI-07 and Taxol ${ }^{\mathrm{TM}}$ as follows: [Treated (NI07 or Taxol $^{\mathrm{TM}}$ ) - blank/control (Untreated)] x 100\%. Cellular Cytotoxicity was calculated following the manufacturer's instructions as follows: ([Absorbance value of control (Untreated cells) - (Treated (NI-07 or Taxol ${ }^{\mathrm{TM}}$ ) - blank (XTT in medium only)]/control) $x$ 100\%. Viability and Cytotoxicity during Recovery were calculated the same way. However, because untreated cells were not used during Recovery, the initial values generated during LC50 for the untreated (control) cells were repeated in the Recovery phase calculations.

Images were generated using an Olympus IX70 inverted microscope under phase contrast conditions with a Lambda 10-2 shutter controller (Sutter Instruments Inc.) and a Hamamatsu Orca - ER high-speed camera. Objectives used were Olympus UPlan/FL $4 \mathrm{X}$ and an Olympus LCPlan/FL $20 \mathrm{X}$ Ph1. Software used for image acquisition was SimplePCI v. 6.

\section{Statistical Analysis}

To determine the effects of NI-07 on breast cancer cells and normal mammary cells, an initial Two-way ANOVA was performed. If the results were significant at $\leq 0.05$, Oneway ANOVA (including Tukey's HSD) was performed. The $p$ value for significance was set at $\leq 0.05$ for the ANOVA. In addition, Cohen's $d$ test for effect size was also performed to measure the strength of the relationship between the means for NI-07- treated and Untreated cells during LC50 and NI07 and Taxol ${ }^{\mathrm{TM}}$-treated cells during recovery. Even with a significant $\mathrm{p}$ value result, the degree of difference of the effect might not be appreciated. Cohen's $d$ allowed a relative statistical assessment of whether NI-07 dramatically outperformed Taxol ${ }^{\mathrm{TM}}$ during Recovery or simply performed comparably. For the purposes of this study, based on the nature of the samples, Cohen's $d$ values over 2.0 were considered to have a significant size effect relative to the cell numbers tested.

\section{RESULTS}

${ }^{1}$ H-NMR Spectroscopy, Mass (MS) Measurements, and Signal Assignments

Although filtering at decreasing temperatures purified the sample, the final sample still consisted of 5 biochemicals in addition to NI-07. Hence, the ${ }^{1} \mathrm{H}-\mathrm{NMR}(600 \mathrm{MHz})$ spectrum of the sample showed an integrated and partly overlapped figure for each of the chemical's peaks (Fig. 1a). In Fig. (1a), NI-07 was found at $\delta$ 6.40-6.42 (doublet), $\delta 5.25-5.40$ (broad quartet), and $\delta 1.46-1.48$ (multiplet); and the rest of the chemicals, namely, 2-methyl-butyric acid, alanine, chlorogenic acid, sinigrin, and valine, were assigned in Fig. (1b). However, these compounds are nonessential to the activation process of NI-07 in treating the cancer cells. The molecular mass of NI-07, which was confirmed to be 191.2 $\mathrm{g} / \mathrm{mol}$, showed that NI-07 exists in a dihydrate form, $\mathrm{C}_{8} \mathrm{H}_{13} \mathrm{NO}_{2} \cdot 2 \mathrm{H}_{2} \mathrm{O}$ (Fig. 2).

\section{Viscosity, Solubility, Density, and Boiling/Melting Point}

Viscosity of the NI-07 aqueous solution $(0.012 \mathrm{mg} / \mathrm{mL})$, detected using the viscometer, was found to be $1.0806 \mathrm{cP}$ [(centipoises): $\left.10^{-3} \mathrm{~kg} /(\mathrm{m} \cdot \mathrm{s})\right]$ at $10^{\circ} \mathrm{C}, 1.0371 \mathrm{cP}$ at $20^{\circ} \mathrm{C}$, $1.0129 \mathrm{cP}$ at $25^{\circ} \mathrm{C}, 0.9828 \mathrm{cP}$ at $30^{\circ} \mathrm{C}$, and $0.9221 \mathrm{cP}$ at $40^{\circ} \mathrm{C}$, and its density was $1.041 \mathrm{~g} / \mathrm{mL}$ at $25^{\circ} \mathrm{C}$. The boiling and melting points of the same solution had a range of 100.021 to $100.023^{\circ} \mathrm{C}$ and -0.098 to $-0.192^{\circ} \mathrm{C}$, respectively, under $1 \mathrm{~atm}$. Due to the fact that the NI-07 extract solution contained 2-methyl-butyric acid, alanine, chlorogenic acid, sinigrin, and valine, the boiling and melting points demonstrated a range, and not a specific temperature. The solubility of the final purified powder in water was 217.22 $\mathrm{g} / 100 \mathrm{~g}$ water at $25^{\circ} \mathrm{C}$.

\section{NI-07 Significantly Affected Breast Cancer Cell Viability in All Breast Cancer Lines Tested}

In order to determine the effectiveness of NI-07 in killing breast cancer cells, NI-07 was compared to Taxol ${ }^{\mathrm{TM}}$ or untreated cultures. From our previous work [37] and the work of others (for review see [42]), Taxol ${ }^{\mathrm{TM}}$ is known to induce apoptosis within the first $24 \mathrm{~h}$. In addition, the morphological changes that occur as a result of $\mathrm{Taxol}^{\mathrm{TM}}$ exposure were observed [43], (i.e., microtubule polymerization, the formation of multiple micronuclei, plasma membrane blebbing, etc.). Morphological changes induced by NI-07 demonstrated features very disparate from Taxol $^{\mathrm{TM}}$. Figs. (3-7) summarize the results for the different cancer cell lines tested. Figs. $(\mathbf{8}, \mathbf{9})$ summarize the data for the normal breast cells tested.

NI-07 Demonstrates Killing Effectiveness in TaxolResistant HCC1419 Cells 


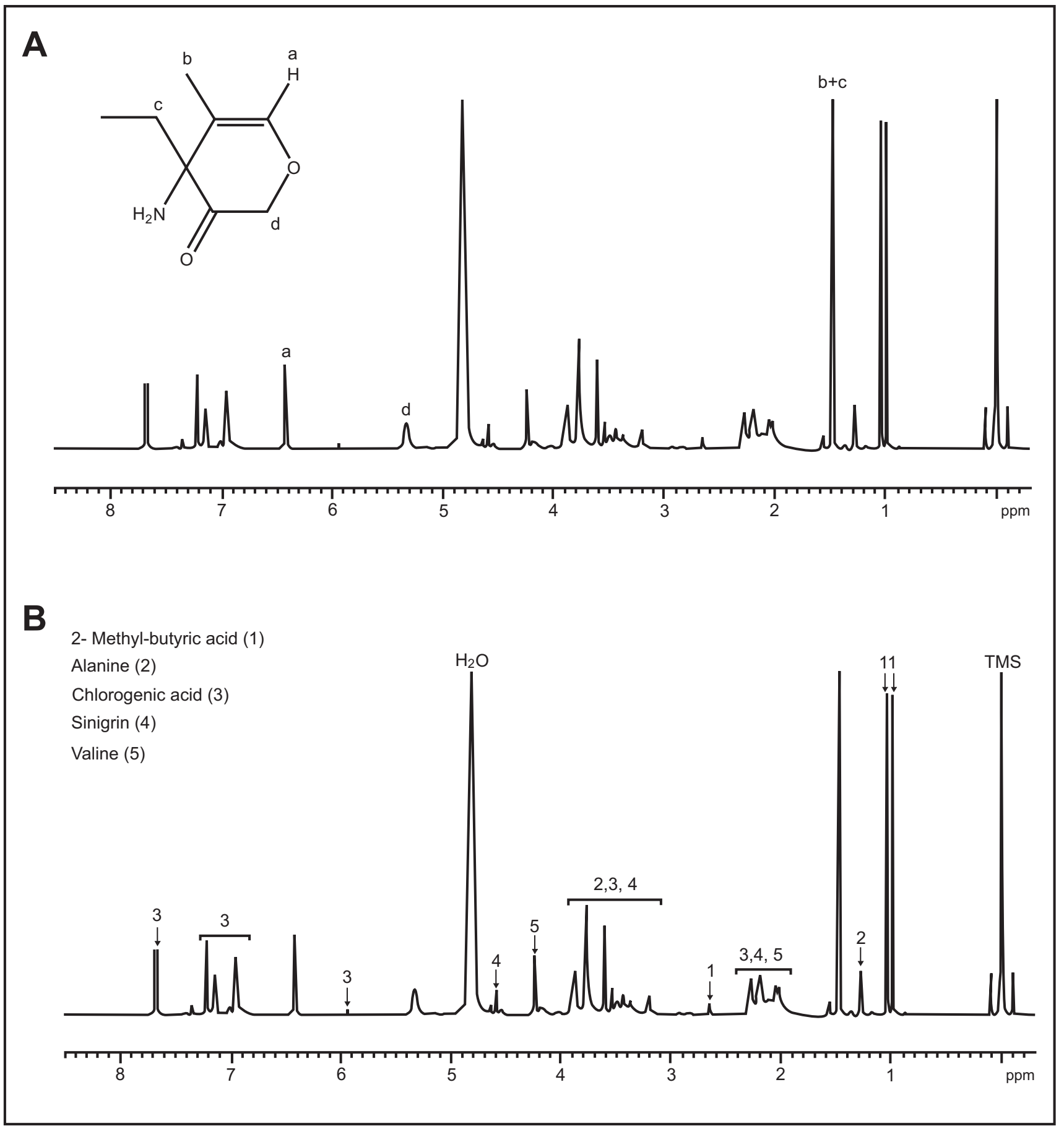

Fig. (1). The main bioreactive components of NI-07 identified by ${ }^{1} \mathrm{H}-\mathrm{NMR}$. (A) Structure of NI-07 and the overlapping chemical peaks. (B) The ${ }^{1} \mathrm{H}-\mathrm{NMR}$ results showing the presence of the reactive moiety as well as the five most reactive components remaining after NI-07 purification.

HCC1419 breast cancer cells were derived from a stage III invasive ductal carcinoma and marker expression profiles

for these cells show that they are ER-, PR-, her2/neu+ and negative for p53 [30]. This cell line was of particular interest based on its reported Taxol ${ }^{\mathrm{TM}}$ resistance [44]. Fig. (3) shows the results of NI-07 and Taxol ${ }^{\mathrm{TM}}$ administration. Fig. (3A, B) demonstrates the contrast in effectiveness of NI-07 and Taxol $^{\mathrm{TM}}$. Within the first $24 \mathrm{~h}$, Taxol ${ }^{\mathrm{TM}}$ shows a significant effect on HCC1419 cell growth compared to untreated and NI-07. However, from $48 \mathrm{~h}$ on, cell growth begins to recover. In contrast, there is an attenuated effect observed with NI-07 exposure (Fig. 3A). After 48 h, a dramatic and significant decline in cell growth was observed that continued throughout Recovery (Fig. 3B). The statistical significance of these observations, determined by 1-way ANOVA, is demonstrated in Fig. (3C). LC50 values show the differences between NI-07 and untreated controls. 


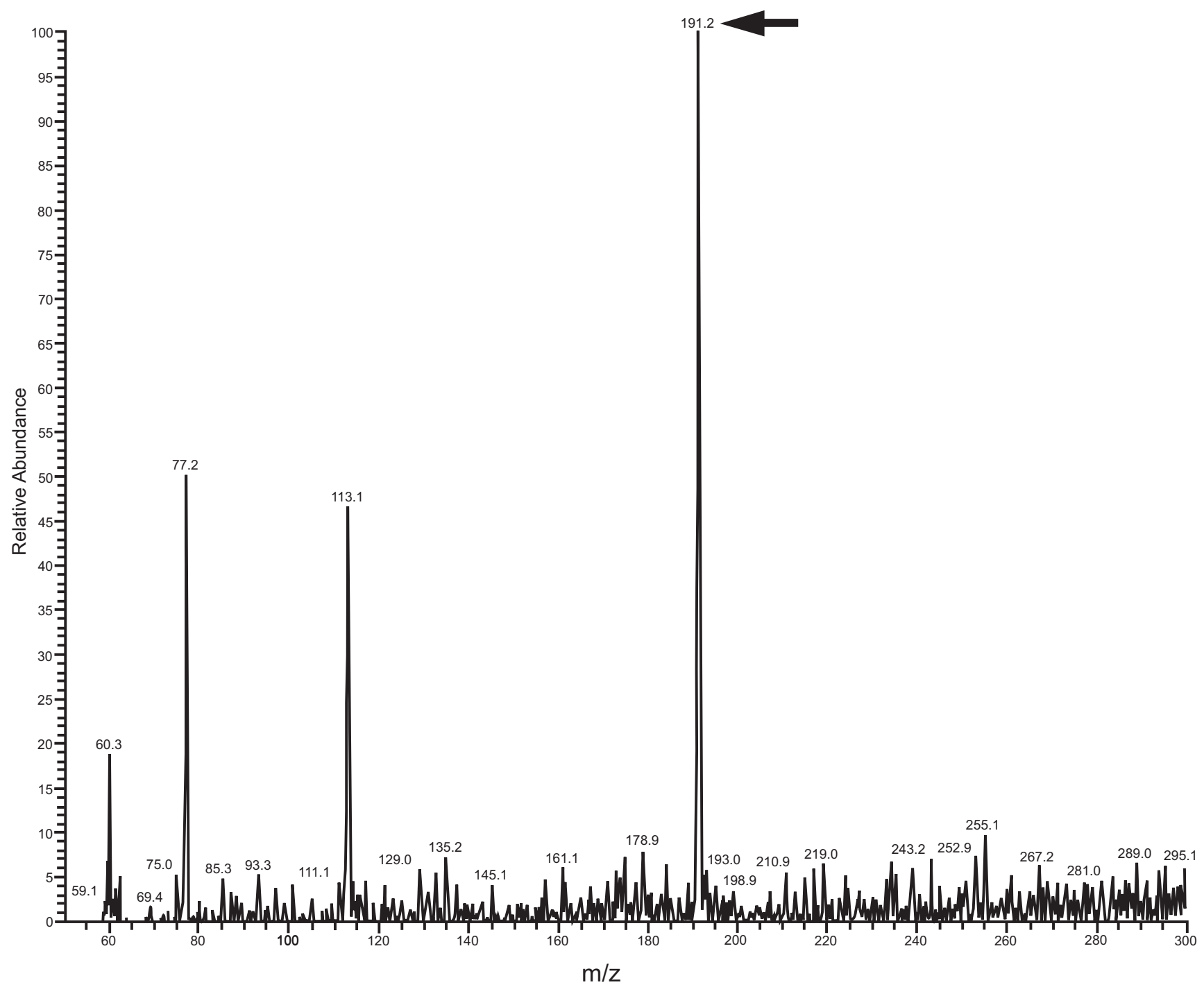

Fig. (2). ESI-MS spectrum of the purified sample showed that the molar mass of NI-07 dihydrate (arrow, $\mathrm{C}_{8} \mathrm{H}_{13} \mathrm{NO}_{2} \cdot 2 \mathrm{H}_{2} \mathrm{O}$ ) is $191.2 \mathrm{~g} / \mathrm{mol}$

Recovery values show the difference in continued efficacy of NI-07 compared to Taxol ${ }^{\mathrm{TM}}$ treatment. Cohen's $d$ was applied as a measure of effect size to statistically gauge how significant the differences between the compared means actually was. In Fig. (3C), the Cohen's $d$ values become highly significant after $48 \mathrm{~h}$, reflecting the observations inferred from Fig. $(\mathbf{3 A}, \mathbf{B})-$ that the effects of NI-07 are more notable from $4 \mathrm{~d}$ through to the experimental endpoint.

Fig. (3D) is a panel of representative photomicrographs of NI-07-treated, Taxol ${ }^{\mathrm{TM}}$-treated and untreated HCC1419 cells taken under phase contrast conditions at $4 \mathrm{~d}$ to demonstrate the difference in timing and appearance of cell response under each condition. Panels in Fig. (3) demonstrate that by $4 \mathrm{~d}$, there is a striking difference in morphology, density of the individual cells and cell number. Cells treated with NI-07 begin to retract from the surface, becoming spherical with noticeable aggregation. Additionally, a distinguishable thickening of the plasma membrane occurs, predominantly in one side (arrows). Taxol ${ }^{\text {TM}}$-treated cells exhibited the flattening and characteristic disruption of metaphase with the resulting formation of multiple mini-nuclei (arrows), while untreated cells demonstrated greater cell numbers in a confluent monolayer. By $4 \mathrm{~d}$ of Recovery, the cultures treated with

NI-07 have been irreversibly affected. Any remaining cells are highly vacuolated, spherical and unattached to the plate whereas, HCC1419 cells treated with Taxol ${ }^{\mathrm{TM}}$ appear to have a quantifiable population of resistant cells (Fig. 3B). Cell viability was determined by Trypan Blue Exclusion and XTT analysis. Day 4 of the first week showed a divergence in viability between Taxol ${ }^{\mathrm{TM}}$ and NI-07 that continued throughout Recovery (week 2). By the end of Recovery, less than $10 \%$ of the cells treated with NI-07 were viable, whereas $\sim 30 \%$ of the Taxol $^{\mathrm{TM}}$-treated cells remained viable (Suppl. Fig. 1). The decrease in cell viability for the untreated controls was attributed to over confluence in the wells. Suppl. Fig. (1B) is misleading because at $48 \mathrm{~h}$, HCC1419 viability shows a spike from $<10 \%$ viability to $50 \%$. However, when the cell count is taken into consideration (1276 cells) this means that $\sim 600$ cells total, may be viable. These results were also confirmed by the photomicrographs (Fig. 3D) and XTT viability analysis (data not shown). Of note is the fact that NI-07 cell counts stayed 


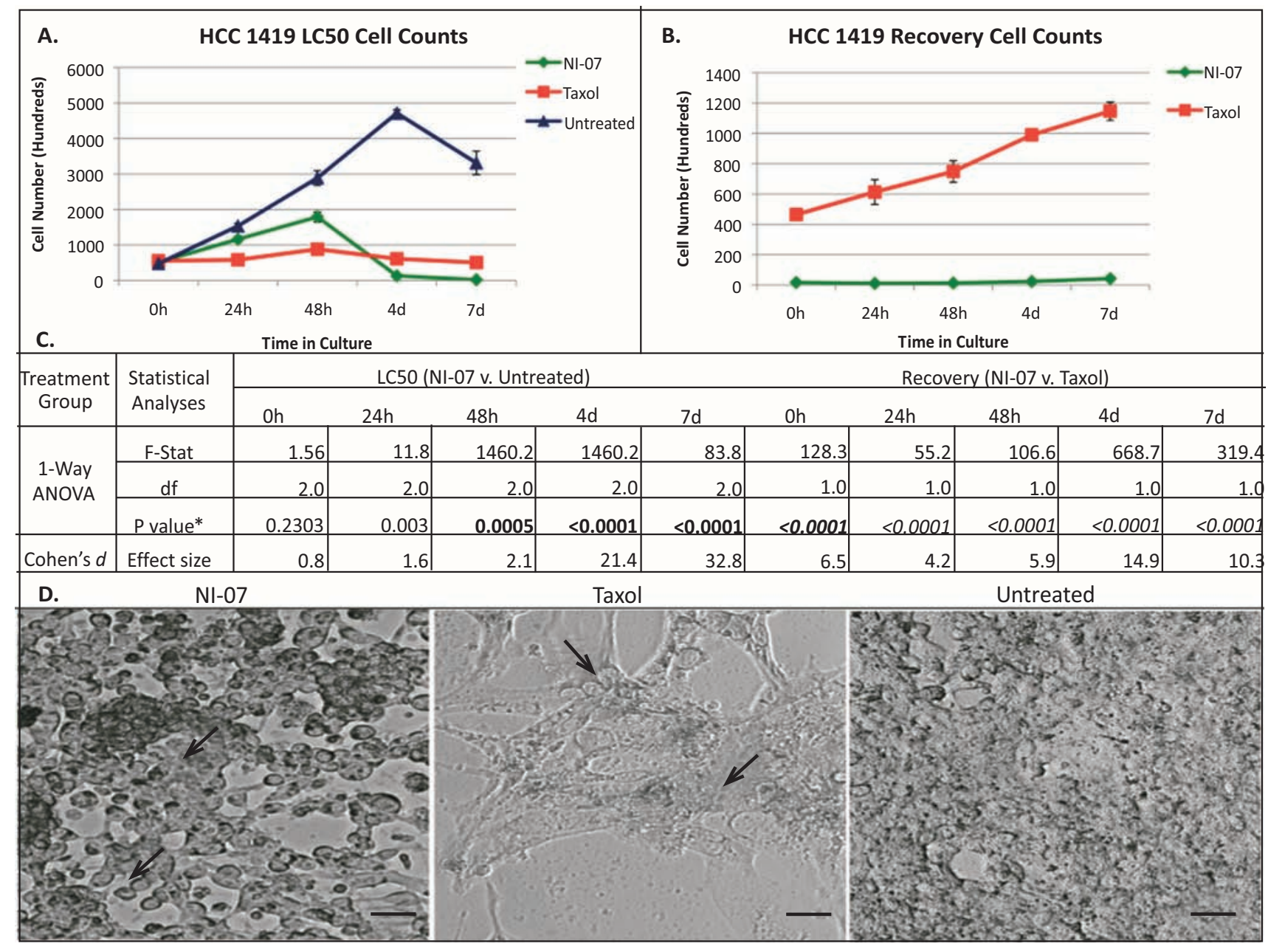

Fig. (3). Results of HCC1419 breast cancer cell treatment with NI-07. Cells were plated and 24 - 48 h later, treated with either NI-07 or Taxol $^{\mathrm{TM}}$. Fresh medium was added on day 3 LC50. (A) Cell counts during week 1 of culture (LC50). Cells were treated with $36.6 \mathrm{mM}$ of NI07 for 7 consecutive days or $2.5 \mu \mathrm{M}$ of Taxol ${ }^{\mathrm{TM}}$ for $24 \mathrm{~h}$, at which time fresh, untreated medium added. (B) Cell counts during week 2 of culture (Recovery). On day 0 (corresponding to $7 \mathrm{~d}$ LC50, cells were counted and with untreated medium was added remaining wells. Medium was also replenished on day 3 of Recovery. (C) Statistical analyses results for NI-07 versus untreated in week 1 and NI-07 versus Taxol $^{\mathrm{TM}}$ in week 2. ${ }^{*}$ Bold $\mathrm{p}$ value indicates statistically significant difference between NI-07 and Untreated. Italicized $\mathrm{p}$ value indicates statistically significant difference between NI-07 and TaxolTM. (D) Representative photomicrographs of cell growth and morphology on day 4 of week 1 for NI-07, Taxol ${ }^{\mathrm{TM}}$ and untreated cell cultures. Arrows indicate morphological traits resulting from differences in mechanisms of action between Taxol ${ }^{\mathrm{TM}}$ and NI-07. Error bars shown are based on standard error of the sample set. Bar scale $=50 \mu \mathrm{m}$.

consistently lower during Recovery than Taxol ${ }^{\mathrm{TM}}$, which ended the study with almost 3 times the total number of cells originally plated (Fig. 3B).

\section{NI-07 Demonstrates Killing Effectiveness in MCF7 Cells}

The MCF7 breast cancer cell line is among the most used and well characterized. These cells are ER+, PR+ and her2/neu+ [45]. Results for MCF7 breast cells are illustrated in Fig. (4). Overall, MCF7 showed results similar to HCC1419 with small differences. In MCF7 cells, differences between NI-07- treated and untreated cells became significant at $48 \mathrm{~h}$ at which time the cell counts suggest that NI-07 halted cell proliferation, maintaining stable turnover until $4 \mathrm{~d}$ when cells were appreciably lost from culture (Fig. 4A, C). During Recovery, there was no significant difference observed between the effects of NI-07 and Taxol ${ }^{\mathrm{TM}}$ on the MCF7 cells (Fig. 4B, C). These results were not surprising considering the sensitivity of MCF7 cells to Taxol ${ }^{\mathrm{TM}}$ [37, 46]. Fig. (4D) shows the phenotypic differences between NI07 and TaxolTM cell morphology. Notably, with NI-07 exposure the overall cell size becomes smaller, the perinuclear area appears disrupted while nuclear perturbations and membrane blebbing are not evident as with Taxol $^{\mathrm{TM}}$ (arrows). Cell viability results showed that NI-07 significantly affected MCF7 cell viability at $48 \mathrm{~h}$ and remained stable during recovery (Suppl. Fig. 2).

\section{NI-07 Demonstrates Similar Results in Killing Effectiveness in TNBC Cells}

The triple negative breast cancer (TNBC) cells MDAMB-468 and MDA-MB-231 are null for wild type ER, PR or her2/neu activity [47]. Figs. $(5,6)$ present the findings for M468 and M231 cells, respectively. When treated with NI07 , the results were very similar with one exception - the 

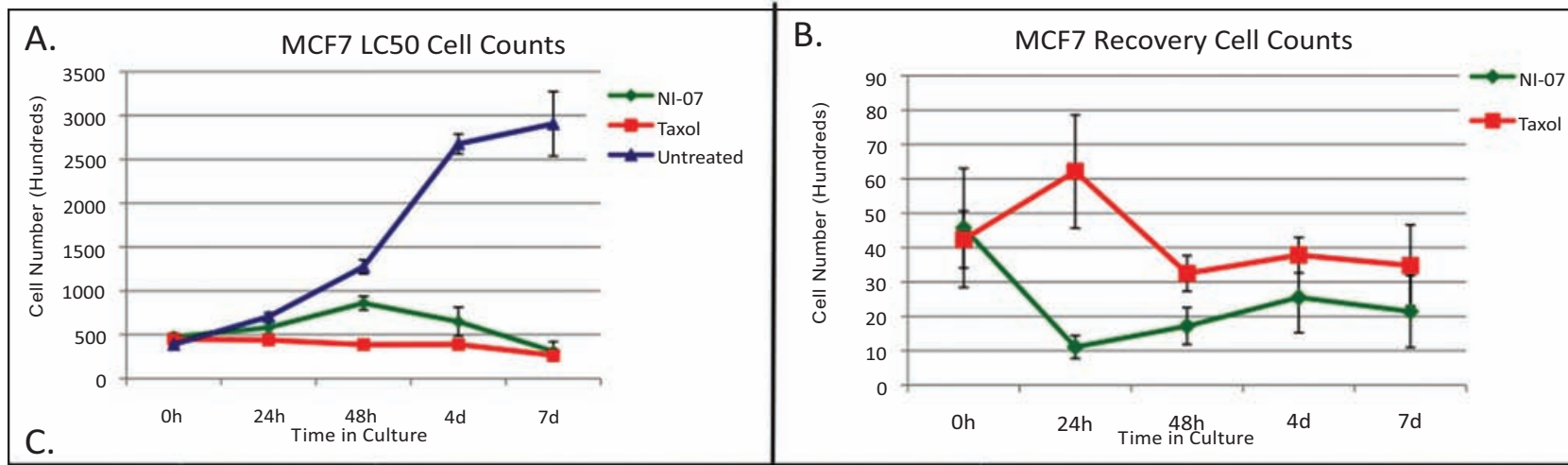

\begin{tabular}{|c|c|c|c|c|c|c|c|c|c|c|c|}
\hline \multirow{2}{*}{$\begin{array}{c}\text { Treatment } \\
\text { Group }\end{array}$} & \multirow{2}{*}{$\begin{array}{c}\text { Statistical } \\
\text { Analyses }\end{array}$} & \multicolumn{5}{|c|}{ LC50 (NI-07 v. Untreated) } & \multicolumn{5}{|c|}{ Recovery (NI-07 v. Taxol) } \\
\hline & & Oh & $24 \mathrm{~h}$ & $48 \mathrm{~h}$ & $4 d$ & $7 \mathrm{~d}$ & $\mathrm{Oh}$ & $24 \mathrm{~h}$ & $48 \mathrm{~h}$ & $4 d$ & $7 d$ \\
\hline \multirow{3}{*}{$\begin{array}{l}\text { 1-Way } \\
\text { ANOVA }\end{array}$} & F-Stat & 1.4 & 6.1 & 40.9 & 70.38 & 45.0 & 0.031 & 9.125 & 4.237 & 1.139 & 0.717 \\
\hline & df & 2.0 & 2.0 & 2.0 & 2.0 & 2.0 & 1.0 & 1.0 & 1.0 & 1.0 & 1.0 \\
\hline & $P$ value & 0.265 & 0.007 & $<0.0001$ & $<0.0001$ & $<0.0001$ & 0.862 & 0.0079 & 0.0562 & 0.3022 & 0.4096 \\
\hline Effect size & Cohen's d & 1.0 & 1.74 & 1.76 & 4.76 & 3.18 & 0.083 & 0.083 & 1.43 & 0.05 & 0.4 \\
\hline
\end{tabular}
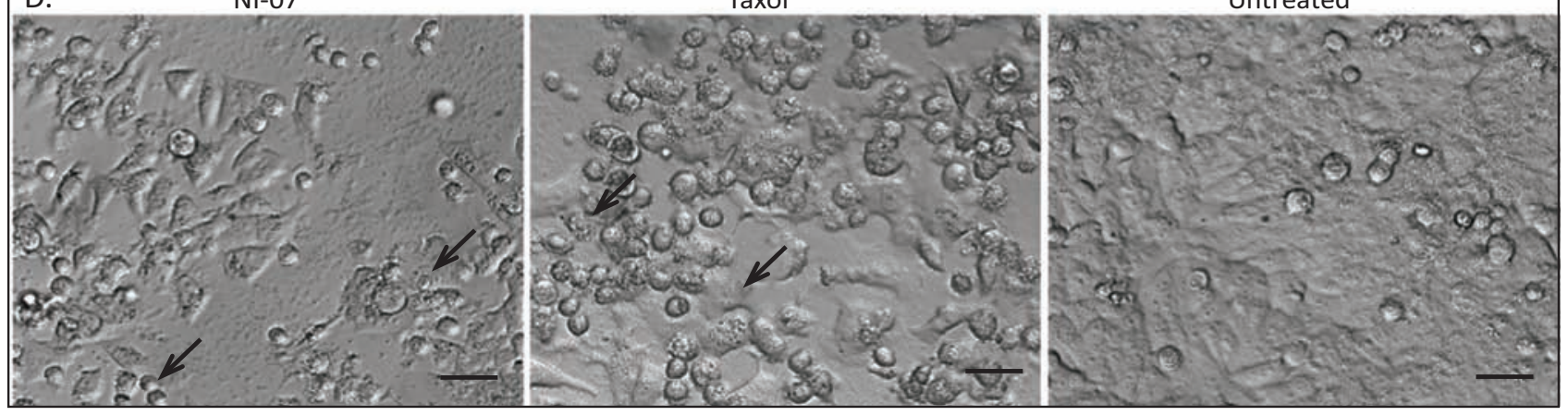

Fig. (4). Results of MCF7 breast cancer cell treatment with NI-07. Cells were plated and 24 - 48 h later, treated with either NI-07 or Taxol ${ }^{\mathrm{TM}}$. Fresh medium was added on day 3 LC50. (A) Cell counts during week 1 of culture (LC50). Cells were treated with $36.6 \mathrm{mM}$ of NI-07 for 7 consecutive days or $2.5 \mu \mathrm{M}$ of Taxol ${ }^{\mathrm{TM}}$ for $24 \mathrm{~h}$, at which time fresh, untreated medium added. (B) Cell counts during week 2 of culture (Recovery). On day 0 (corresponding to $7 \mathrm{~d}$ LC50, cells were counted and with untreated medium was added remaining wells. Medium was also replenished on day 3 of Recovery. (C) Statistical analyses results for NI-07 versus untreated in week 1 and NI-07 versus Taxol ${ }^{\mathrm{TM}}$ in week 2. *Bold $\mathrm{p}$ value indicates statistically significant difference between NI-07 and Untreated. Italicized p value indicates statistically significant difference between NI-07 and Taxol ${ }^{\mathrm{TM}}$. (D) Representative photomicrographs of cell growth and morphology on day 4 of week 1 for NI-07, Taxol ${ }^{\mathrm{TM}}$ and untreated cell cultures. Arrows indicate morphological traits resulting from differences in mechanisms of action between Taxol ${ }^{\mathrm{TM}}$ and NI-07. Error bars shown are based on standard error of the sample set. Bar scale $=50 \mu \mathrm{m}$.

M468 cells demonstrated sensitivity and cell death to NI-07 after $24 \mathrm{~h}$ exposure. Cell growth declined very rapidly through LC50 (Fig. 5A). However, there was no statistical difference in response between NI-07 and Taxol ${ }^{\mathrm{TM}}$ during Recovery (Fig. 5B). Cell viability demonstrated a more gradual decline until $4 \mathrm{~d}$ at which time viability decreased rapidly (Suppl. Fig. 3). Fig. (5D) illustrates the morphological changes associated with NI-07 that differ from Taxol ${ }^{\mathrm{TM}}$, namely condensation in the perinuclear area with the nucleus appearing relatively unaffected (arrows).

MDA-MB-231 cells were similarly affected by NI-07 treatment (Fig. 6). However, while these cells became more resistant to $\mathrm{Taxol}^{\mathrm{TM}}$ with time, they were not able to recover from NI-07 exposure (Fig. 6B, C). Cell viability data represents three independent experiments. However, the percent viable cells at $\sim 35$ on day 7 of Recovery (Fig. $6 \mathbf{E}$ ) needs to be considered in the context of total cells counted.

The cell numbers for these replicates averaged 2000 versus 32,000 for Taxol ${ }^{\text {TM}}$ - treated cells (Fig. 6B).

\section{SKBR3 Cells Showed the Most Resistance to NI-07}

SKBR3 cells over express her2/neu and are ER/PR negative [48]. Fig. (7) shows the results obtained for the SBBR3 cells. As noted in Fig. (7A, C), there was no statistically significant difference from untreated cells until 7 $\mathrm{d}$. While Taxol ${ }^{\mathrm{TM}}$ showed slightly better results on $4 \mathrm{~d}$ and 7d in LC50 (Fig. 7A), there was a significant divergence during Recovery (Fig. 7B). Although the growth curves were similar in trends, NI-07 was observed to have a significantly greater effect on cell death (Fig. 7B, C). Fig. (7D) contrasts 


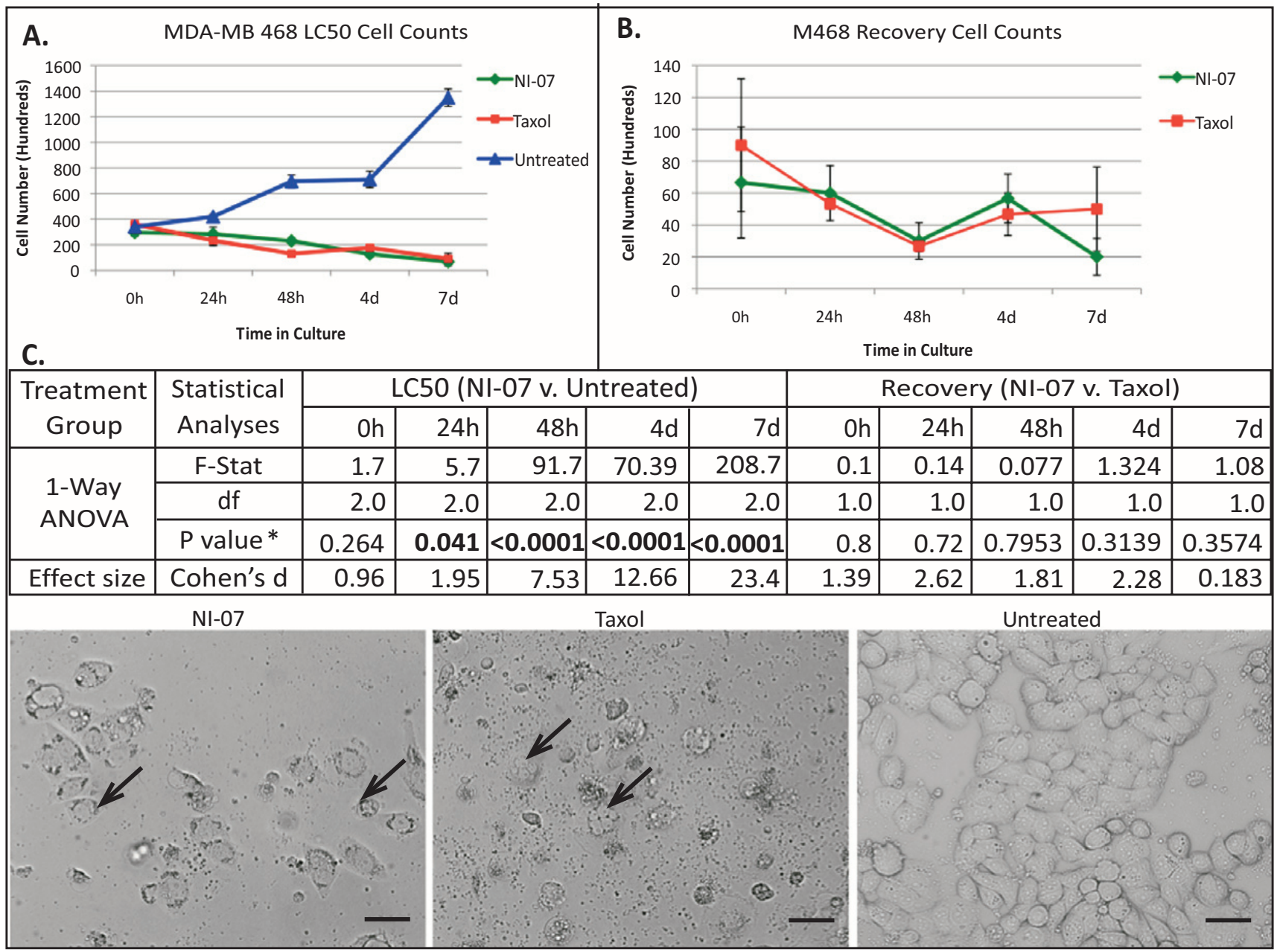

Fig. (5). Results of MDA-MB-468 breast cancer cell treatment with NI-07. Cells were plated and 24-48 h later, treated with either NI-07 or Taxol $^{\mathrm{TM}}$. Fresh medium was added on day 3 LC50. (A) Cell counts during week 1 of culture (LC50). Cells were treated with $36.6 \mathrm{mM}$ of NI07 for 7 consecutive days or $2.5 \mu \mathrm{M}$ of Taxol $^{\mathrm{TM}}$ for $24 \mathrm{~h}$, at which time fresh, untreated medium added. (B) Cell counts during week 2 of culture (Recovery). On day 0 (corresponding to $7 \mathrm{~d}$ LC50, cells were counted and with untreated medium was added remaining wells. Medium was also replenished on day 3 of Recovery. (C) Statistical analyses results for NI-07 versus untreated in week 1 and NI-07 versus $\mathrm{Taxol}^{\mathrm{TM}}$ in week 2. ${ }^{*}$ Bold $\mathrm{p}$ value indicates statistically significant difference between NI-07 and Untreated. Italicized $\mathrm{p}$ value indicates statistically significant difference between NI-07 and Taxol ${ }^{\mathrm{TM}}$. (D) Representative photomicrographs of cell growth and morphology on day 4 of week 1 for NI-07, Taxol ${ }^{\mathrm{TM}}$ and untreated cell cultures. Arrows indicate morphological traits resulting from differences in mechanisms of action between Taxol ${ }^{\mathrm{TM}}$ and NI-07. Error bars shown are based on standard error of the sample set. Bar scale $=50 \mu \mathrm{m}$.

the phenotypic changes associated with NI-07 action compared with Taxol ${ }^{\mathrm{TM}}$ activity (arrows).

\section{NI-07 Showed No Cytotoxicity to Normal Breast Cell Types Tested}

One of the major stumbling blocks to developing effective cancer treatments is the effect of the anticancer agent on the normal cells. Since the impact of anticancer agents on the normal cells can have profound consequences for patient response [49], we included two normal cell types found in breast tissue; diploid human mammary epithelial cells (HME) and normal human fibroblasts. The HME cells were immortalized with the catalytic subunit of human telomerase (designated HT). Studies have shown that telomerase-immortalized cells maintain genomic stability [50]. The second normal cell type was the skin fibroblast cell strain CCD-1074sk. These cells were derived from the skin overlaying normal breast tissue taken from a mastectomy patient. Figs. $(\mathbf{8}, 9)$ show the results obtained from treatment of these cell types with NI-07 and Taxol ${ }^{\mathrm{TM}}$.

HME cells treated with NI-07 (Fig. 8) continued to proliferate and exhibited a smooth, vacuole-free cytoplasm (Fig. 8D) characteristic of unstressed cells [51]. Note that when treated with Taxol ${ }^{\mathrm{TM}}$ there was evident loss of cells from culture, cells acquired a flattened, stressed appearance, blebbing, and disrupted nuclear formation (Fig. 8A, D). Growth curves in Recovery showed that HME cells treated with NI-07 continued to growth in contrast to Taxol ${ }^{\mathrm{TM}}$ treated cells, which plateaued (Fig. 8B). Furthermore, oneway ANOVA for cell growth demonstrated that there was no significant difference between the untreated cells and the NI07- treated cells. During the Recovery portion of the experiment, the level of significance between NI-07 and 

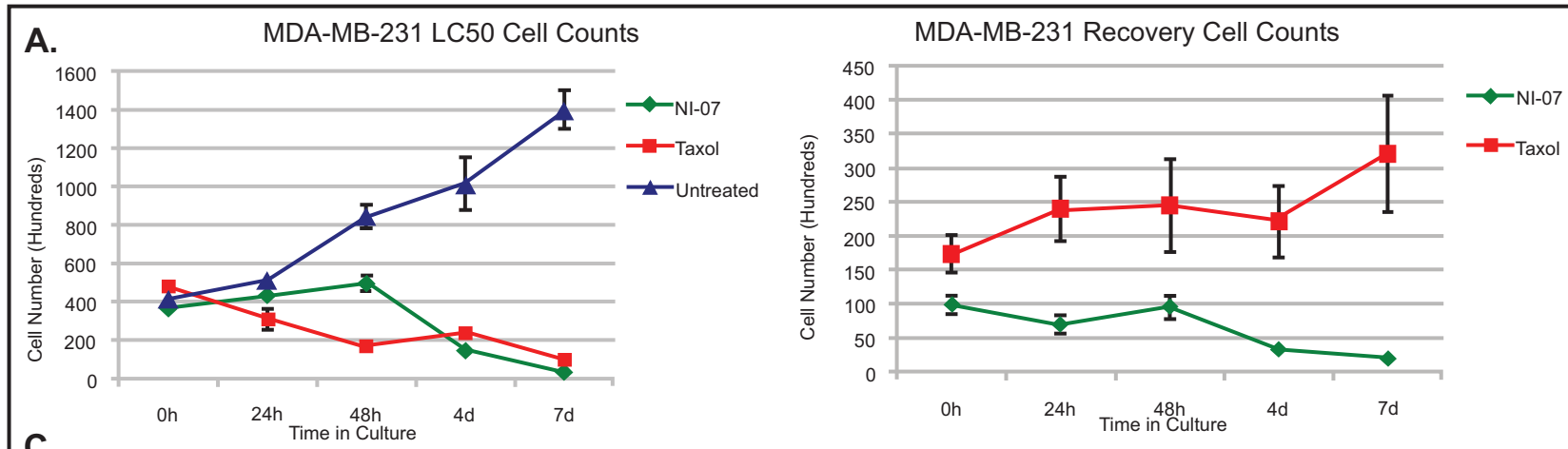

C.

\begin{tabular}{|c|c|c|c|c|c|c|c|c|c|c|c|}
\hline \multirow{2}{*}{$\begin{array}{c}\text { Treatment } \\
\text { Group }\end{array}$} & \multirow{2}{*}{$\begin{array}{l}\text { Statistical } \\
\text { Analyses }\end{array}$} & \multicolumn{5}{|c|}{ LC50 (NI-07 v. Untreated) } & \multicolumn{5}{|c|}{ Recover y (NI-07 v. Taxol) } \\
\hline & & $\mathrm{Oh}$ & $24 \mathrm{~h}$ & $48 \mathrm{~h}$ & $4 d$ & $7 \mathrm{~d}$ & $\mathrm{Oh}$ & $24 \mathrm{~h}$ & $48 \mathrm{~h}$ & $4 d$ & $7 \mathrm{~d}$ \\
\hline \multirow{3}{*}{$\begin{array}{l}\text { 1-Way } \\
\text { ANOVA }\end{array}$} & \multirow{3}{*}{$\begin{array}{c}\begin{array}{c}\text { F-Stat } \\
\text { df }\end{array} \\
\text { P value* }\end{array}$} & 2.21 & 5.5 & 58.0 & 35.31 & 153.57 & 5.99 & 12.21 & 4.62 & 12.91 & 12.11 \\
\hline & & 2.0 & 2.0 & 2.0 & 2.0 & 2.0 & 1.0 & 1.0 & 1.0 & 1.0 & 1.0 \\
\hline & & 0.19 & 0.044 & 0.0001 & 0.0005 & $<0.0001$ & 0.0706 & 0.025 & 0.098 & 0.023 & 0.025 \\
\hline Effect size & Cohen's $d$ & 0.75 & 1.26 & 4.08 & 5.12 & 10.93 & 1.99 & 2.85 & 8.25 & 2.93 & 2.84 \\
\hline
\end{tabular}

D. MDA-MB-231 LC50 Cell Counts

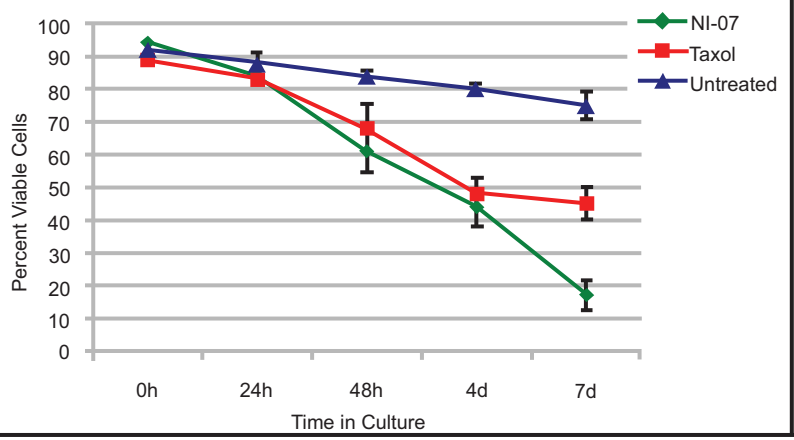

E.

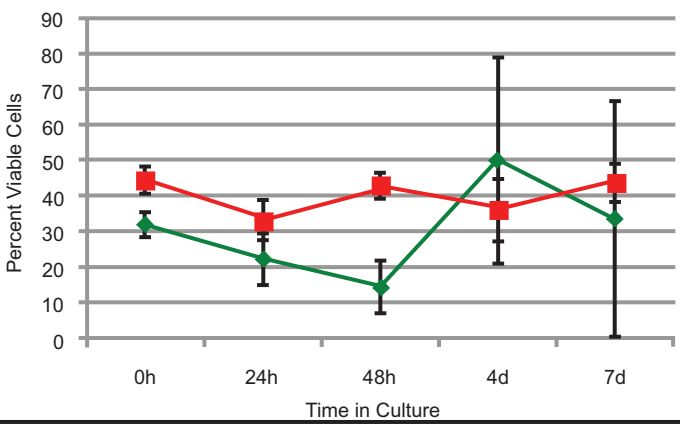

Fig. (6). Representative results of cell counts and viability for MDA-MB-231 breast cancer cell treatment with NI-07. Cells were plated and 24 - $48 \mathrm{~h}$ later, treated with either NI-07 or Taxol ${ }^{\mathrm{TM}}$. Fresh medium was added on day 3 LC50. (A) Cell counts during week 1 of culture (LC50). Cells were treated with $36.6 \mathrm{mM}$ of NI-07 for 7 consecutive days or $2.5 \mu \mathrm{M}$ of Taxol ${ }^{\mathrm{TM}}$ for $24 \mathrm{~h}$, at which time fresh, untreated

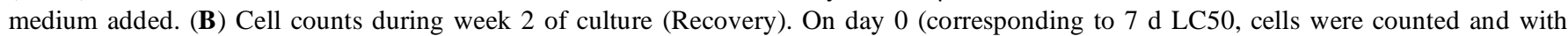
untreated medium was added remaining wells. Medium was also replenished on day 3 of Recovery. (C) Statistical analyses results for NI-07 versus untreated in week 1 and NI-07 versus Taxol ${ }^{\mathrm{TM}}$ in week $2 .{ }^{*}$ Bold $\mathrm{p}$ value indicates statistically significant difference between NI-07 and Untreated. Italicized $\mathrm{p}$ value indicates statistically significant difference between NI-07 and Taxol ${ }^{\mathrm{TM}}$. (D) Determination of percent viable cells by Trypan Blue exclusion during LC50. (E) Determination of percent viable cells by Trypan Blue exclusion during Recovery.

Taxol ${ }^{\mathrm{TM}}$ cells was very high. Cell viability analysis showed that the NI-07- treated cells maintained greater than $70 \%$ viability - comparable to untreated. In contrast, Taxol ${ }^{\mathrm{TM}}$ had a significant impact on cell viability (Suppl. Fig. 5). In addition, Taxol ${ }^{\mathrm{TM}}$ was shown to be cytotoxic to HME cells by XTT, whereas NI-07 showed no cytotoxicity in LC50 (Suppl. Fig. 5C, D). The slight rise in cytotoxicity of NI-07 during Recovery is most likely due to increased cell number, confluence and growth in the same well plates for 2 weeks.

The mammary skin fibroblast cells showed results similar to HME cells (Fig. 8). CCDsk cell growth in NI-07 paralleled untreated controls very closely (Fig. 9A, C). Due to the rapid cell proliferation, the CCDsk cell treated with NI-07 decreased in cell number during Recovery (Fig. 9C). Indeed, in several wells, the cells were so confluent they lifted off the plates in large sheets. However, side-by-side comparisons to Taxol ${ }^{\mathrm{TM}}$-treated fibroblasts showed significant differences in cell number (Fig. 9B, C), with percent viable cells greater than $80 \%$ throughout the experiment (Suppl. Fig. 6A, B). Photomicrographs reveal very distinct differences in cell morphology in NI-07 and Taxol ${ }^{\text {TM}}$ - treated cultures. Phase contrast images show that the fibroblast cells treated with Taxol ${ }^{\mathrm{TM}}$ exhibit perturbations in cell shape, nuclear division and membrane integrity as well as increased vacuole formation (arrows). In sharp contrast, the fibroblast cells treated with NI-07 demonstrated smooth cytosols, intact cell membranes and unperturbed nuclei. Cytotoxicity of determined by XTT demonstrated that NI-07 was less toxic than Taxol ${ }^{\mathrm{TM}}$ (Suppl. Fig. 6C, D).

No statistical difference was observed between untreated cells and those cultures treated with NI-07. However, there is a profound difference in cells treated with Taxol ${ }^{\mathrm{TM}}$. Divergence from the mean number between sample sets of NI-07 and Taxol ${ }^{\mathrm{TM}}$ is significant to 0.0001. Cohen's $d$ analysis of effect size yielded no significant differences between NI-07- treated cells and untreated controls. 


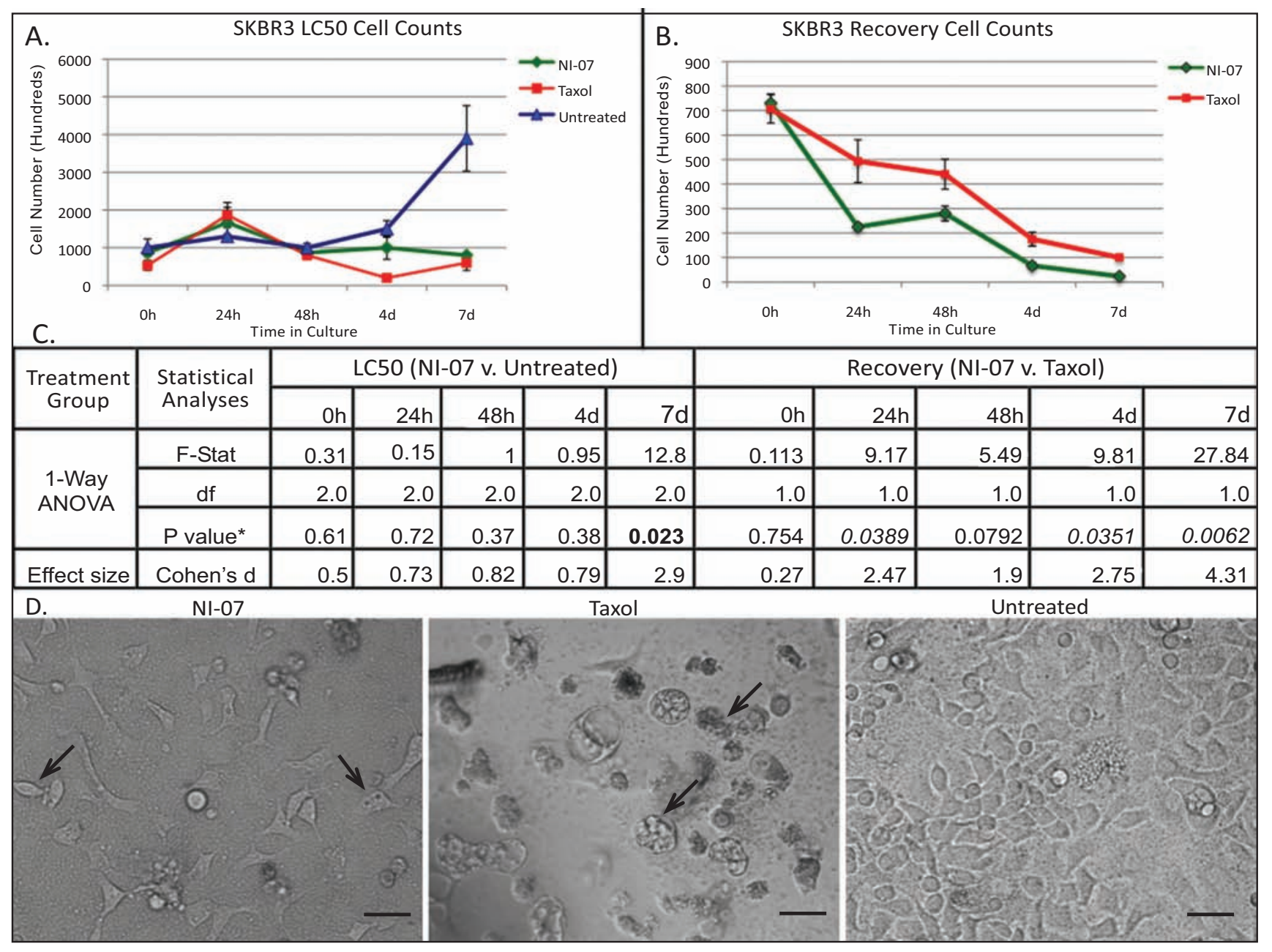

Fig. (7). Results of SKBR3 breast cancer cell treatment with NI-07. Cells were plated and 24-48 h later, treated with either NI-07 or Taxol ${ }^{\mathrm{TM}}$. Fresh medium was added on day 3 LC50. (A) Cell counts during week 1 of culture (LC50). Cells were treated with $36.6 \mathrm{mM}$ of NI-07 for 7 consecutive days or $2.5 \mu \mathrm{M}$ of Taxol ${ }^{\mathrm{TM}}$ for $24 \mathrm{~h}$, at which time fresh, untreated medium added. (B) Cell counts during week 2 of culture (Recovery). On day 0 (corresponding to $7 \mathrm{~d}$ LC50, cells were counted and with untreated medium was added remaining wells. Medium was also replenished on day 3 of Recovery. (C) Statistical analyses results for NI-07 versus untreated in week 1 and NI-07 versus Taxol ${ }^{\mathrm{TM}}$ in week 2. *Bold p value indicates statistically significant difference between NI-07 and Untreated. Italicized p value indicates statistically significant difference between NI-07 and Taxol ${ }^{\mathrm{TM}}$. (D) Representative photomicrographs of cell growth and morphology on day 4 of week 1 for NI-07, Taxol ${ }^{\mathrm{TM}}$ and untreated cell cultures. Arrows indicate morphological traits resulting from differences in mechanisms of action between Taxol ${ }^{\mathrm{TM}}$ and NI-07. Error bars shown are based on standard error of the sample set. Bar scale $=50 \mu \mathrm{m}$.

However, when analyzing the cells in Recovery, there is a sharp increase in effect size, attributed to Taxol ${ }^{\mathrm{TM}}$-induced cell death (Fig. 7C, 8C), indicating that the normal cells grow very well in the presence of NI-07 but are significantly affected by Taxol ${ }^{\mathrm{TM}}$.

\section{DISCUSSION}

Three of the major issues in drug development are effectively targeting the cancer cells, water-solubility and cytotoxicity to normal cells [52]. Many candidate antitumor agents show strong potential in vitro. Unfortunately, in many cases, normal cells are not tested alongside the tumor cells. Thus the effects on normal cells are not documented. The current agents used for solid tumor treatments are very effective at killing the cancer cells. Additionally, resistant cancer cells can be destroyed using different combinations of agents that affect specific aspects of the cell such as mitosis (e.g. Taxol ${ }^{\mathrm{TM}}$ ), DNA repair (e.g Doxorubicin), or protein synthesis (e.g. Cytoxin). However, in killing the cancer cells, normal cells, tissues and organ systems are also greatly affected. Thus, the patient endures debilitating side effects. This is in part due to the delivery methods. The majority of anti-cancer agents are not water-soluble. Therefore, they are dissolved in a vehicle such as Cremophor ${ }^{\mathrm{TM}}$, which also causes dramatic side effects. As a result, patients are treated aggressively for short periods of time and then given several weeks to recover before the next round. Newer, watersoluble agents include Abraxane ${ }^{\circledR}$, which is paclitaxel bound to albumin [14]. While protein bound paclitaxel can be administered more quickly and is considered water-soluble $[15,53]$, the underlying problems with side effects and damage to normal, healthy cells and tissues still remains. As such, treatment effectiveness is still based not only on cancer 


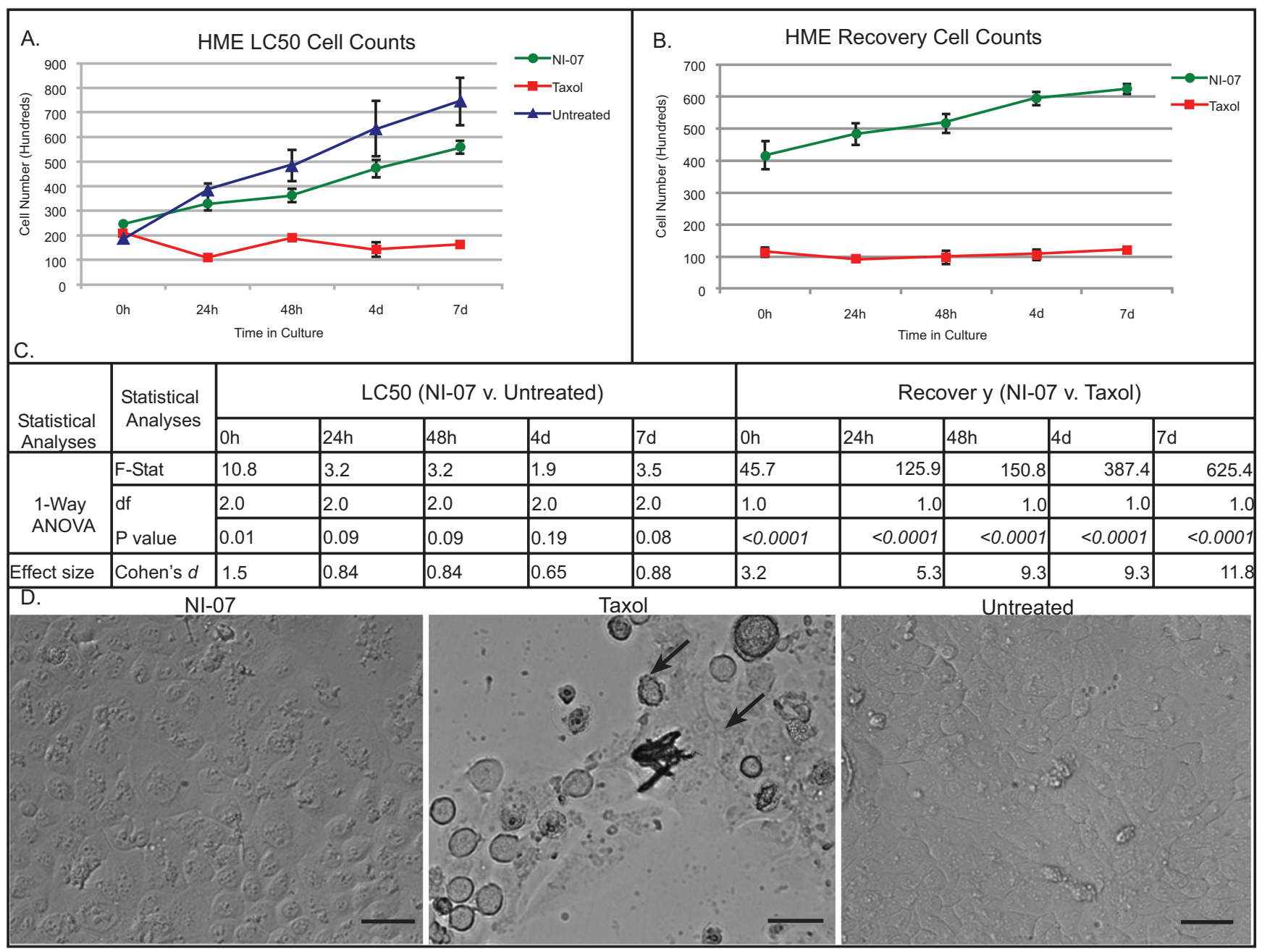

Fig. (8). Results of normal human mammary breast cell treatment with NI-07. HME cells were plated and 24 - $48 \mathrm{~h}$ later, treated with either NI-07 or Taxol ${ }^{\mathrm{TM}}$. Fresh medium was added on day 3 LC50. (A) Cell counts during week 1 of culture (LC50). Cells were treated with 36.6 $\mathrm{mM}$ of NI-07 for 7 consecutive days or $2.5 \mu \mathrm{M}$ of Taxol ${ }^{\mathrm{TM}}$ for $24 \mathrm{~h}$, at which time fresh, untreated medium added. (B) Cell counts during week 2 of culture (Recovery). On day 0 (corresponding to $7 \mathrm{~d}$ LC50, cells were counted and with untreated medium was added remaining wells. Medium was also replenished on day 3 of Recovery. (C) Statistical analyses results for NI-07 versus untreated in week 1 and NI-07 versus Taxol ${ }^{\mathrm{TM}}$ in week 2 . *Bold $\mathrm{p}$ value indicates statistically significant difference between NI-07 and Untreated. Italicized $\mathrm{p}$ value indicates statistically significant difference between NI-07 and Taxol ${ }^{\mathrm{TM}}$. (D) Representative photomicrographs of cell growth and morphology on day 4 of week 1 for NI-07, Taxol ${ }^{\mathrm{TM}}$ and untreated cell cultures. Arrows indicate morphological traits resulting from differences in mechanisms of action between Taxol ${ }^{\mathrm{TM}}$ and NI-07. Error bars shown are based on standard error of the sample set. Bar scale $=$ $50 \mu \mathrm{m}$.

stage at diagnosis, but also patient responsiveness and the overall health of the patient $[41,54-56]$.

Another stopgap in developing effective anticancer agents is the lack of translation into the clinic. For the number of potential anticancer agents tested, only a small percentage progress to clinical trials. One reason for this bottleneck is the cytotoxicity of the agent. Without the ability to effectively select cancer cells for destruction, the whole body becomes the target.

\section{CONCLUSION}

Here we present compelling data for a potential new "Green" anticancer compound derived from the Greater Burdock, Arctium lappa. The reactive species identified by ${ }^{1} \mathrm{H}-\mathrm{NMR}$ was NeoImmune ${ }^{\circledR}-07$ or NI-07 demonstrates selective destruction of all the breast cancer cells tested while showing little to no cytotoxicity to the normal cells.

Furthermore, NI-07 is $100 \%$ water-soluble. In comparison to the current anti-tumor agents such as Taxol ${ }^{\mathrm{TM}}$, NI-07 performed comparably or better in killing cancer cells. In the case of more resistant cells such as SKBR3, the attenuated and longer lasting effects of NI-07 could be advantageous. Hypothetically, the clinician could give smaller concentrations for longer periods of time without

affecting the patient's quality of life. Furthermore, water solubility allows for the treatment to be administered either orally (in pill form) or intravenously.

We are currently dissecting the mechanism of action to determine how this compound, under controlled conditions 


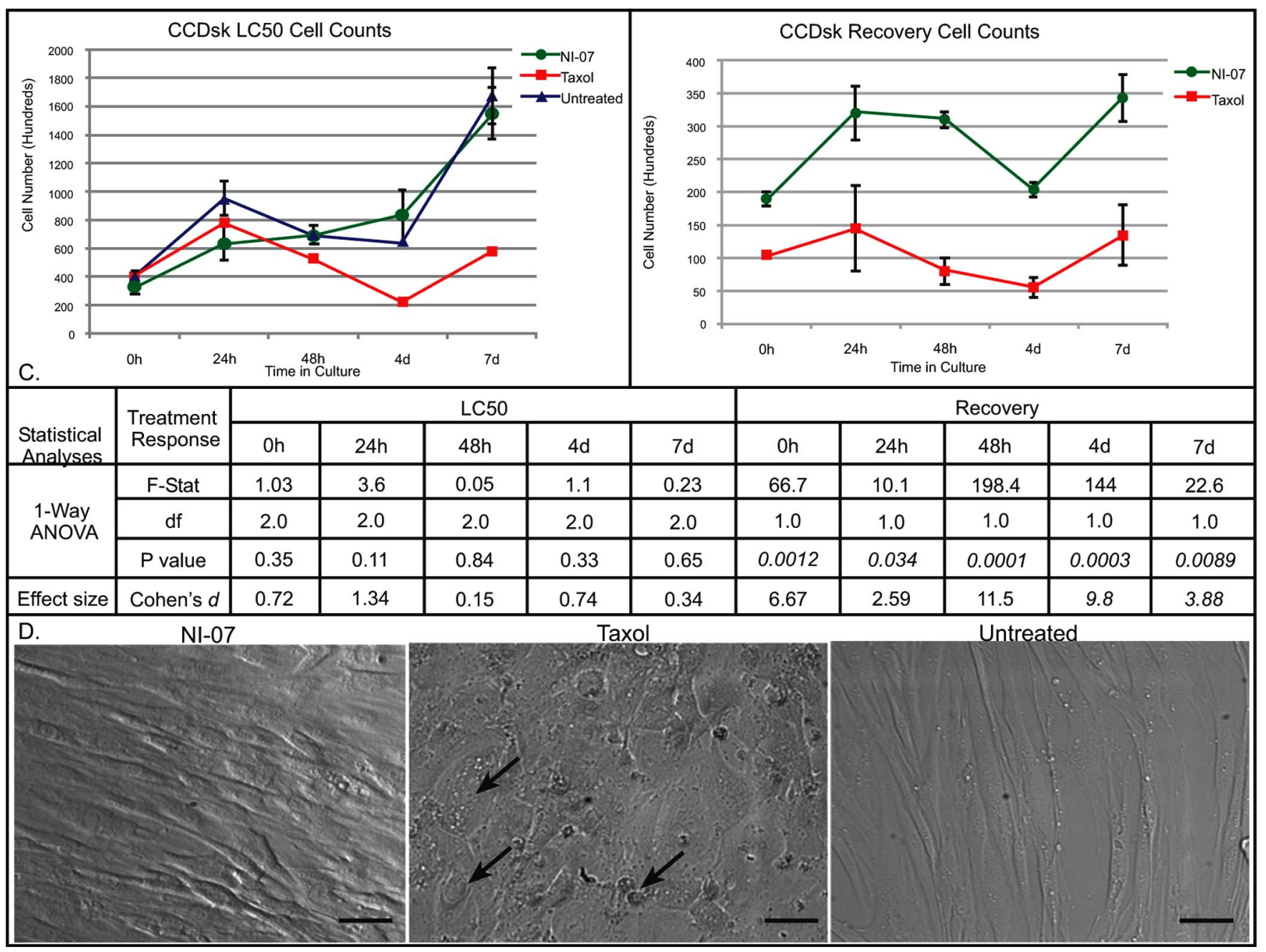

Fig. (9). Results of normal human mammary skin cell treatment with NI-07. CCDsk cells were plated and 24 - $48 \mathrm{~h}$ later, treated with either NI-07 or Taxol ${ }^{\mathrm{TM}}$. Fresh medium was added on day 3 LC50. A) Cell counts during week 1 of culture (LC50). Cells were treated with 36.6 $\mathrm{mM}$ of NI-07 for 7 consecutive days or $2.5 \mu \mathrm{M}$ of Taxol ${ }^{\mathrm{TM}}$ for $24 \mathrm{~h}$, at which time fresh, untreated medium added. B) Cell counts during week 2 of culture (Recovery). On day 0 (corresponding to $7 \mathrm{~d}$ LC50, cells were counted and with untreated medium was added remaining wells. Medium was also replenished on day 3 of Recovery. C) Statistical analyses results for NI-07 versus untreated in week 1 and NI-07 versus Taxol ${ }^{\mathrm{TM}}$ in week 2 . ${ }^{*}$ Bold $\mathrm{p}$ value indicates statistically significant difference between NI-07 and Untreated. Italicized $\mathrm{p}$ value indicates statistically significant difference between NI-07 and Taxol. D) Representative photomicrographs of cell growth and morphology on day 4 of week 1 for NI-07, Taxol ${ }^{\mathrm{TM}}$ and untreated cell cultures. Arrows indicate morphological traits resulting from differences in mechanisms of action between Taxol ${ }^{\mathrm{TM}}$ and NI-07. Error bars shown are based on standard error of the sample set. Bar scale $=50 \mu \mathrm{m}$.

kills only the cancer cells as well as the method of cell death, i.e. apoptosis, autophagy or paraptosis. Future work includes investigating the bioactivation of NI-07 in vitro when exposed to the cytochrome p450 superfamily of monooxygenases and in vivo assays using a mouse model system to determine whether it is as effective in a physiologically relevant environment.

\section{ACKNOWLEDGEMENTS}

We wish to thank the TTU Imaging Center for access to imaging instrumentation. Also, we wish to acknowledge the TTU Biotechnology Core Facilities for access to the Thermolyne Speed Vacuum Centrifuge and Plate Reader.

\section{GRANT SUPPORT}

This study was supported through a grant from Yusahng LLC to JS Park (Korea) and LS Gollahon (USA). Funds were also provided by the TTU Office of the Vice President for Research (LS Gollahon).

\section{CONFLICTS OF INTEREST}

None declared.

\section{SUPPLEMENTARY MATERIAL}

This article is also accompanied with supplementary material and it can be viewed at publisher's website.

\section{REFERENCES}

[1] Jemal A, Bray F, Center MM, Ferlay J, Ward E, Forman D. Global cancer statistics. CA Cancer J Clin 2011; 61(2): 69-90.

[2] Skildum A, Dornfeld K, Wallace K. Mitochondrial amplification selectively increases doxorubicin sensitivity in breast cancer cells with acquired antiestrogen resistance. Breast Cancer Res Treat 2011; 129(3): 785-97. 
[3] Breast Cancer Facts and Figures. Avaialble from: http://ww5.ko men.org/Breast Cancer/Statistics.html [Accessed: August 11, 2011].

[4] Kugawa F, Ueno A, Kawasaki M, Aoki M. Evaluation of cell death caused by CDF (cyclophosphamide, doxorubicin, 5-fluorouracil) multi-drug administration in the human breast cancer cell line MCF-7. Biol Pharm Bull 2004; 27(3): 392-8.

[5] Mozaffari F, Lindemalm C, Choudhury A, et al. Systemic immune effects of adjuvant chemotherapy with 5-fluorouracil, epirubicin and cyclophosphamide and/or radiotherapy in breast cancer: a longitudinal study. Cancer Immunol Immunother 2009; 58(1): 11120.

[6] Menendez JA, Colomer R, Lupu R. Inhibition of tumor-associated fatty acid synthase activity enhances vinorelbine (Navelbine)induced cytotoxicity and apoptotic cell death in human breast cancer cells. Oncol Rep 2004; 12(2): 411-22.

[7] Braun DP, Crist KA, Shaheen F, Staren ED, Andrews S, Parker J. Aromatase inhibitors increase the sensitivity of human tumor cells to monocyte-mediated, antibody-dependent cellular cytotoxicity. Am J Surg 2005; 190(4): 570-1.

[8] Salami S, Karami-Tehrani F. Biochemical studies of apoptosis induced by tamoxifen in estrogen receptor positive and negative breast cancer cell lines. Clin Biochem 2003; 36(4): 247-53.

[9] Sledge GW, Jr., Robert N, Sparano JA, et al. Eastern Cooperative Oncology Group studies of paclitaxel and doxorubicin in advanced breast cancer. Semin Oncol 1995; 22(3 Suppl 6): 105-8.

[10] Merlin JL, Barberi-Heyob M, Bachmann N. In vitro comparative evaluation of trastuzumab (Herceptin) combined with paclitaxel (Taxol) or docetaxel (Taxotere) in HER2-expressing human breast cancer cell lines. Ann Oncol 2002; 13(11): 1743-8.

[11] Wadkins RM, Potter PM, Vladu B, et al. Water soluble 20(S)glycinate esters of 10,11-methylenedioxycamptothecins are highly active against human breast cancer xenografts. Cancer Res 1999; 59(14): 3424-8.

[12] Endo M, Miwa M, Ura M, et al. A water soluble prodrug of a novel camptothecin analog is efficacious against breast cancer resistance protein-expressing tumor xenografts. Cancer Chemother Pharmacol 2010; 65(2): 363-71.

[13] Vittar NB, Awruch J, Azizuddin K, Rivarola V. Caspaseindependent apoptosis, in human MCF-7c3 breast cancer cells, following photodynamic therapy, with a novel water-soluble phthalocyanine. Int J Biochem Cell Biol 2010; 42(7): 1123-31.

[14] Miele E, Spinelli GP, Tomao F, Tomao S. Albumin-bound formulation of paclitaxel (Abraxane ABI-007) in the treatment of breast cancer. Int J Nanomedicine 2009; 4: 99-105.

[15] Feng Z, Zhao G, Yu L, Gough D, Howell SB. Preclinical efficacy studies of a novel nanoparticle-based formulation of paclitaxel that out-performs Abraxane. Cancer Chemother Pharmacol 2010; 65(5): 923-30.

[16] O'Connor TL, Kossoff E. Delayed seizure associated with paclitaxel-Cremophor el in a patient with early-stage breast cancer. Pharmacotherapy 2009; 29(8): 993-6.

[17] Villano JL, Mehta D, Radhakrishnan L. Abraxane induced lifethreatening toxicities with metastatic breast cancer and hepatic insufficiency. IND 2006; 24(5): 455-56.

[18] Klippstein A, Schneider CP, Sayer HG, Hoffken K. Pneumocystis carinii pneumonia as a complication of bendamustine monotherapy in a patient with advanced progressive breast cancer. J Cancer Res Clin Oncol. 2003 May;129(5):316-9.

[19] Iaffaioli RV, Frasci G, Tortora G, et al. Effect of thymic extract 'thymostimulin' on the incidence of infections and myelotoxicity during adjuvant chemotherapy for breast cancer. Thymus 1988; 12(2): 69-75.

[20] Perez-Ellis C, Goncalves A, Jacquemier J, et al. Cost-Effectiveness Analysis of Trastuzumab (Herceptin) in HER2-Overexpressed Metastatic Breast Cancer. Am J Clin Oncol 2009 [Epub ahead of print].

[21] Harries M, Smith I. The development and clinical use of trastuzumab (Herceptin). Endocr Relat Cancer 2002; 9(2): 75-85.

[22] Tu CM, Chu KM, Yang SP, Cheng SM, Wang WB. Trastuzumab (Herceptin)-associated cardiomyopathy presented as new onset of complete left bundle-branch block mimicking acute coronary syndrome: a case report and literature review. Am J Emerg Med 2009; 27(7): e901-3.
[23] Matsuoka H, Furusawa M, Tomoda H, Seo Y. Difference in cytotoxicity of paclitaxel against neoplastic and normal cells. Anticancer Res 1994; 14(1A): 163-7.

[24] Plants Database. Avaialble from: http://plants.usda.gov/java/pro file?symbol=ARLA3 [Accessed: August 11, 2011].

[25] Tierra M, Tierra L. Chinese Traditional Herbal Medicine Vol. II Materia Medica \& Herbal Resource. Twin Lakes, WI: Lotus Press; 1998.

[26] Awale S, Lu J, Kalauni SK, et al. Identification of arctigenin as an antitumor agent having the ability to eliminate the tolerance of cancer cells to nutrient starvation. Cancer Res 2006; 66(3): 1751-7.

[27] Hirose M, Yamaguchi T, Lin C, et al. Effects of arctiin on PhIPinduced mammary, colon and pancreatic carcinogenesis in female Sprague-Dawley rats and MeIQx-induced hepatocarcinogenesis in male F344 rats. Cancer Lett 2000; 155(1): 79-88.

[28] Predes FS, Ruiz AL, Carvalho JE, Foglio MA, Dolder H. Antioxidative and in vitro antiproliferative activity of Arctium lappa root extracts. BMC Complement Altern Med 2011; 11: 25.

[29] Yao X, Zhu F, Zhao Z, Liu C, Luo L, Yin Z. Arctigenin enhances chemosensitivity of cancer cells to cisplatin through inhibition of the STAT3 signaling pathway. J Cell Biochem 2011; 112(10): 2837-49.

[30] Gazdar AF, Kurvari V, Virmani A, et al. Characterization of paired tumor and non-tumor cell lines established from patients with breast cancer. Int J Cancer 1998; 78(6): 766-74.

[31] Soule HD, Vazguez J, Long A, Albert S, Brennan M. A human cell line from a pleural effusion derived from a breast carcinoma. J Natl Cancer Inst 1973; 51(5): 1409-16.

[32] Cailleau R, Young R, Olive M, Reeves WJ, Jr. Breast tumor cell lines from pleural effusions. J Natl Cancer Inst 1974; 53(3): 66174.

[33] Cailleau R, Olive M, Cruciger QV. Long-term human breast carcinoma cell lines of metastatic origin: preliminary characterization. In Vitro 1978; 14(11): 911-5.

[34] Trempe GL. Human breast cancer in culture. Recent Results Cancer Res 1976; 57: 33-41.

[35] Shay JW, Tomlinson G, Piatyszek MA, Gollahon LS. Spontaneous in vitro immortalization of breast epithelial cells from a patient with Li-Fraumeni syndrome. Mol Cell Biol1995; 15(1): 425-32.

[36] Herbert BS, Wright AC, Passons CM, et al. Effects of chemopreventive and antitelomerase agents on the spontaneous immortalization of breast epithelial cells. J Natl Cancer Inst 2001; 93(1): 39-45.

[37] Pan Z, Gollahon L. Taxol Directly Induces Endoplasmic Reticulum-Associated Calcium Changes That Promote Apoptosis in Breast Cancer Cells. Breast J 2011; 17(1): 56-70.

[38] Blajeski AL, Kottke TJ, Kaufmann SH. A multistep model for paclitaxel-induced apoptosis in human breast cancer cell lines. Exp Cell Res 2001; 270(2): 277-88.

[39] Wang M, Cornett B, Nettles J, Liotta DC, Snyder JP. The Oxetane Ring in Taxol. J Org Chem 2000; 65(4): 1059-68.

[40] Fan W. Possible mechanisms of paclitaxel-induced apoptosis Biochemical Pharmacology 1999; 57(11): 1215-21.

[41] Tewari M, Krishnamurthy A, Shukla HS. Predictive markers of response to neoadjuvant chemotherapy in breast cancer. Surg Oncol 2008; 17(4): 301-11.

[42] McGrogan BT, Gilmartin B, Carney DN, McCann A. Taxanes, microtubules and chemoresistant breast cancer. Biochimica et biophysica acta 2008; 1785(2): 96-132.

[43] Chen L, Zheng S, Willingham MC. Mechanism of taxol-induced apoptosis in human breast cancer cells. Zhonghua Zhong Liu Za Zhi 1997; 19(2): 103-6.

[44] Mechetner E, Kyshtoobayeva A, Zonis S, et al. Levels of multidrug resistance (MDR1) P-glycoprotein expression by human breast cancer correlate with in vitro resistance to taxol and doxorubicin. Clin Cancer Res 1998; 4(2): 389-98.

[45] Creighton CJ, Massarweh S, Huang S, et al. Development of resistance to targeted therapies transforms the clinically associated molecular profile subtype of breast tumor xenografts. Cancer Res 2008; 68(18): 7493-501.

[46] Bacus SS, Gudkov AV, Lowe M, et al. Taxol-induced apoptosis depends on MAP kinase pathways (ERK and p38) and is independent of p53. Oncogene 2001; 20(2): 147-55.

[47] Chougule MB, Patel AR, Jackson T, Singh M: Antitumor activity of Noscapine in combination with Doxorubicin in triple negative breast cancer. PLoS One 2011; 6(3): e17733. 
[48] Neve RM, Sutterluty H, Pullen N, Lane HA, Daly JM, Krek W, Hynes NE: Effects of oncogenic ErbB2 on G1 cell cycle regulators in breast tumour cells. Oncogene 2000; 19(13): 1647-56.

[49] Kaelin WG, Jr. Synthetic lethality: a framework for the development of wiser cancer therapeutics. Genome Med 2009; 1(10): 99 .

[50] McChesney PA, Turner KC, Jackson-Cook C, Elmore LW, Holt SE. Telomerase resets the homeostatic telomere length and prevents telomere dysfunction in immortalized human cells. DNA Cell Biol 2004; 23(5): 293-300.

[51] Herr I, Debatin KM. Cellular stress response and apoptosis in cancer therapy. Blood 2001; 98(9): 2603-14.

[52] Sherbenou DW, Druker BJ. Applying the discovery of the Philadelphia chromosome. J Clin Invest 2007; 117(8): 2067-74.
[53] Iglesias J. nab-Paclitaxel (Abraxane(R)): an albumin-bound cytotoxic exploiting natural delivery mechanisms into tumors. BCR 2009; 11(Suppl 1): S21.

[54] Defossez G, Mathoulin-Pelissier S, Ingrand I, et al. Satisfaction with care among patients with non-metastatic breast cancer: development and first steps of validation of the REPERES-60 questionnaire. BMC Cancer 2007; 7: 129.

[55] Fernandez-Sanchez M, Gamboa-Dominguez A, Uribe N, et al. Clinical and pathological predictors of the response to neoadjuvant anthracycline chemotherapy in locally advanced breast cancer. Med Oncol 2006; 23(2): 171-83.

[56] Goldhirsch A, Colleoni M, Domenighetti G, Gelber RD. Systemic treatments for women with breast cancer: outcome with relation to screening for the disease. Ann Oncol 2003; 14(8): 1212-4.

(c) Gollahon et al.; Licensee Bentham Open.

This is an open access article licensed under the terms of the Creative Commons Attribution Non-Commercial License (http://creativecommons.org/licenses/by-nc/ 3.0/) which permits unrestricted, non-commercial use, distribution and reproduction in any medium, provided the work is properly cited. 